\title{
$\begin{array}{lllllllll}\text { I } & \mathrm{N} & \mathrm{S} & \mathrm{T} & \mathrm{I} & \mathrm{T} & \mathrm{U} & \mathrm{T} & \mathrm{E}\end{array}$
}

\section{Rural Demographic Change in the New Century Slower Growth, Increased Diversity}

$\mathrm{R}$ ural America encompasses nearly 75 percent of the land area of the United States, and it is home to 51 million people. Demographic trends in this vast area are far from monolithic. Some rural regions have experienced decades of sustained growth, while large segments of the agricultural heartland continue to lose people and institutions. Nonmetropolitan America has also been buffeted by a variety of cyclical forces, including the recent economic recession, new immigration, and population aging. ${ }^{1}$ Population growth in rural America reflects a balancing act between natural increase (births minus deaths) and net migration (in-migrants minus out-migrants). Both play an important role in rural population change, but the influence of each varies across time and location.

This brief examines rural demographic trends in the first decade of the twenty-first century using newly available data from the 2010 Census. The demographic changes that are reshaping rural America are increasingly important to policies and plans designed to increase the viability of rural communities and enhance their contribution to the nation's material, environmental and social well-being.

Figure 1. Nonmetropolitan Demographic Change, 1930 TO 2010

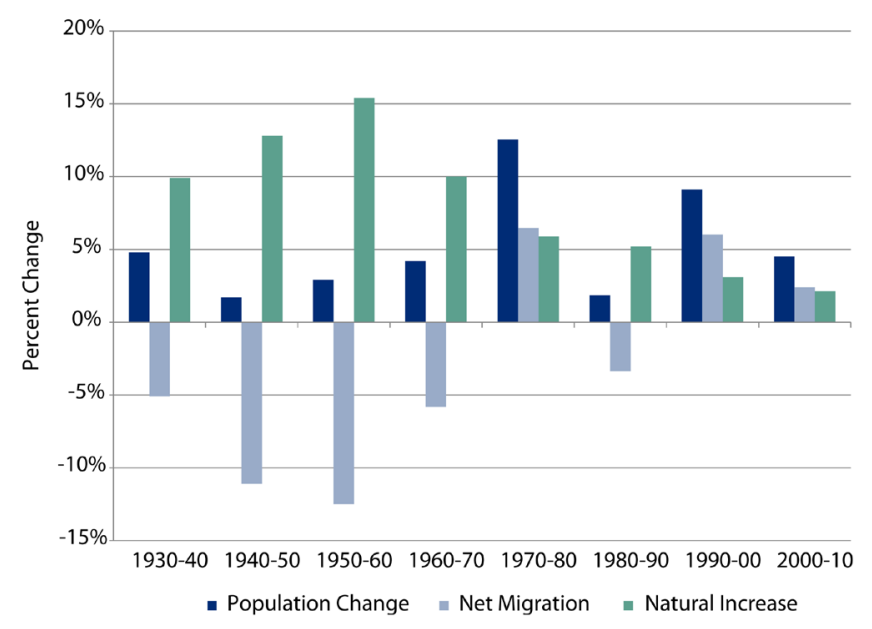

Source: U.S. Census 1930-2010 and FSCPE

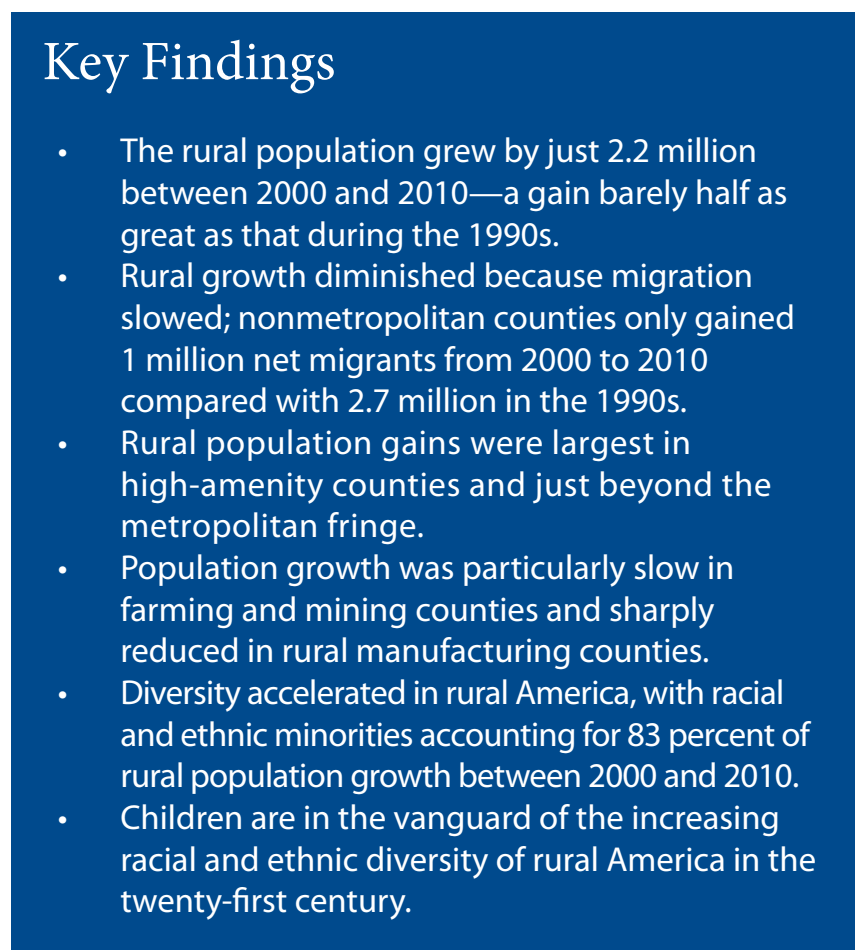

\section{Historical Trends}

The history of rural population change illustrates the complex interplay between migration and natural increase. The large surplus of births over deaths that sustained nonmetropolitan population growth during much of the twentieth century has dwindled. As a result, migration's ebb and flow has come to play a larger role in determining whether nonmetropolitan areas grow or decline.

Throughout most of the twentieth century, nonmetropolitan areas experienced widespread outmigration (Figure 1). The magnitude of the migration loss varied from decade to decade, but the pattern was consistent: more people left rural areas than arrived. These historical trends changed abruptly in the 1970s 
when rural population gains exceeded those in metropolitan areas for the first time in the twentieth century. The remarkable turnaround, however, ended in the 1980s as widespread out migration and population decline reemerged. Trends once again rebounded in the early 1990s before slowing near the end of the decade. ${ }^{2}$ Thus, at the dawn of the twenty-first century, the demographic implications of natural increase and net migration for the future of rural America are once again in question.

\section{Some Rural Areas Grow, Others Continue to Decline}

In the first decade of the twenty-first century, patterns of population growth and decline varied widely across rural America (Figure 2). Population gains were greatest in the West and Southeast, as well as at the periphery of large urban areas in the Midwest and Northeast. Scattered areas of population gain also were evident in recreational areas of the upper Great Lakes, the Ozarks, and northern New England. In contrast, population losses were common in the Great Plains and Corn Belt, in the Mississippi Delta, in parts of the northern Appalachians, and in the industrial and mining belts of New York and Pennsylvania.

Nonmetropolitan population growth slowed precipitously after 2000, to half that of the 1990s. Between 2000 and 2010, rural counties gained 2.2 million residents (4.5 percent) to reach a population of 51 million in April 2010. During the 1990s, the rural population gain was 4.1 million. The population gains were greater in nonmetropolitan counties adjacent to metropolitan areas just as they were from 1990 to 2000 (Figure 3). These adjacent counties saw a 5.5 percent population gain between 2000 and 2010, but it was still just 57 percent of what it had been

Figure 2. Nonmetropolitan POPUlATion CHANGE, 2000 TO 2010

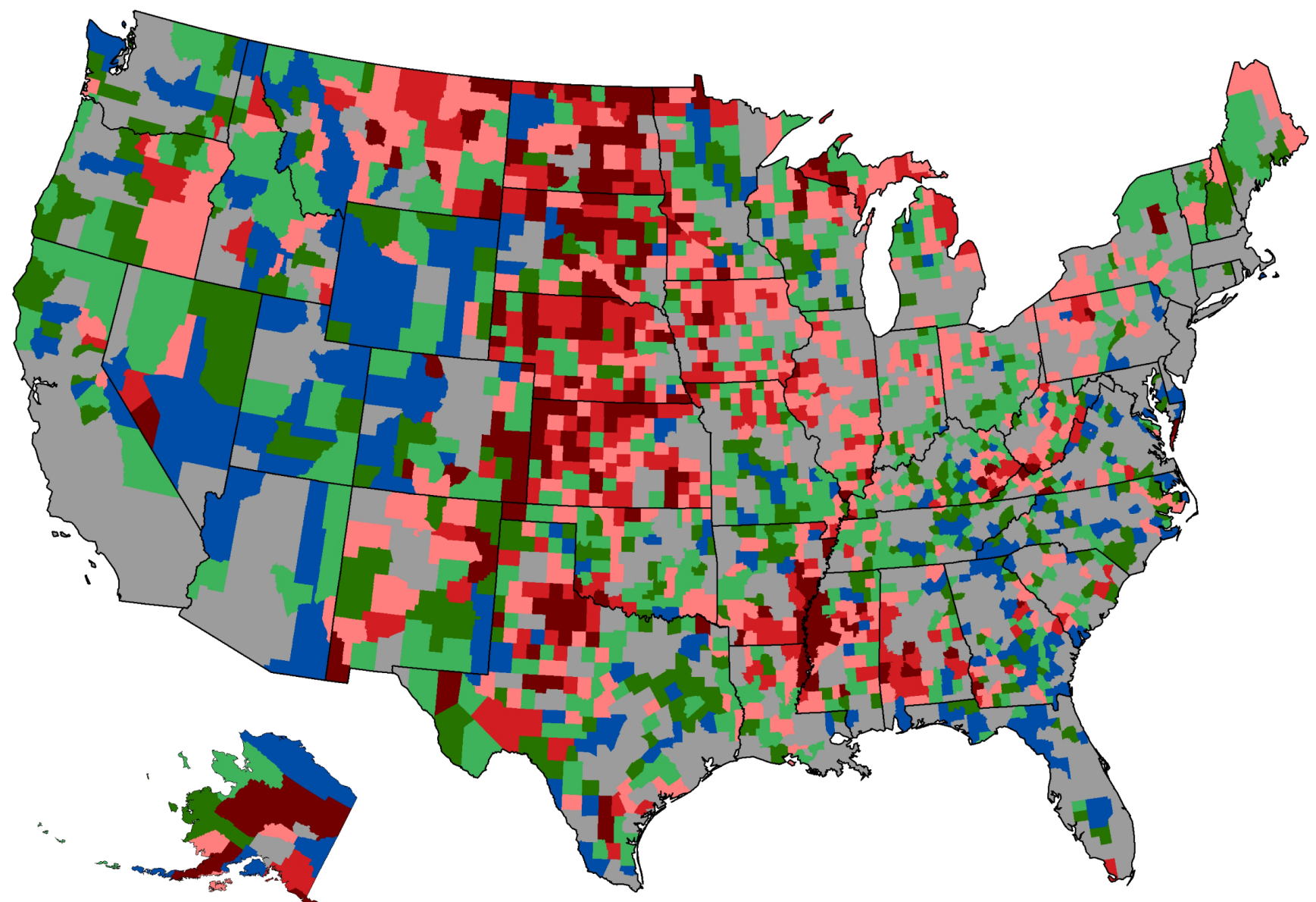

Metropolitan Counties

Loss greater than $10 \%$

Loss 5 to $10 \%$

Gain 0 to $5 \%$

Loss 0 to $5 \%$

Gain 5 to $10 \%$

Gain greater than $10 \%$ 
Figure 3. DEMOgRAPHIC CHANGE IN METROPOLITAN

AND NONMETROPOLITAN AREAS, 1990-2000, 2000-2010

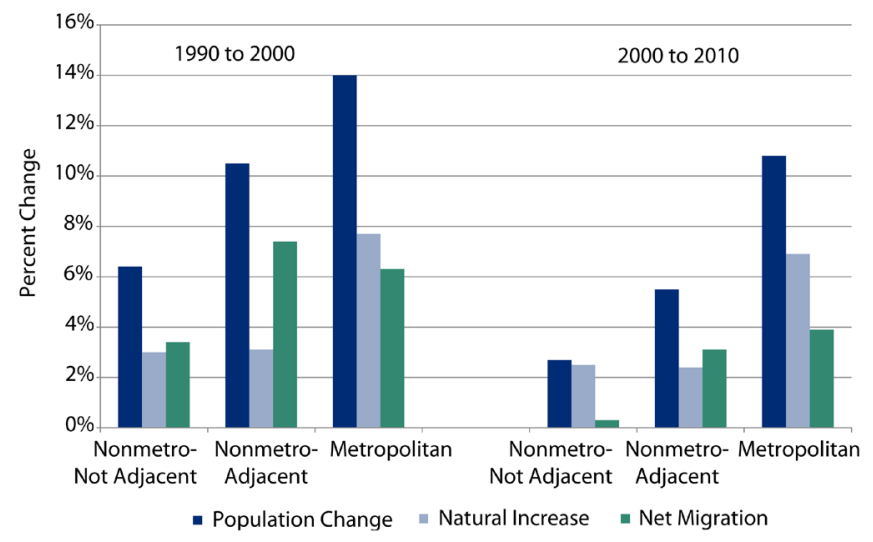

Source: U.S. Census 1990-2010 and FSCPE

during the 1990s. Among more remote rural counties, the gain was considerably smaller (2.7 percent), or just 42 percent of the gain during the 1990s. Population gains in metropolitan areas also diminished (from 14.0 percent to 10.8 percent), but the reduction was much more modest. A key question is how the interplay of migration and natural increase combined to produce the slower nonmetropolitan population growth after 2000 .

\section{Balancing Natural Increase and Net Migration}

The absence of significant migration gains after 2000 was the primary cause of the sharply curtailed rural population growth. During the 1990s, migration accounted for nearly two-thirds of the entire nonmetropolitan population gain. After 2000, it accounted for less than one-half of the gain. Nonmetropolitan counties gained 2.7 million residents from migration during the 1990s, but only about 1.0 million between 2000 and 2010. Migration gains also occurred in fewer rural counties. Only 46 percent of the rural counties experienced a net migration gain between 2000 and 2010 compared with 65 percent between 1990 and 2000. Because natural increase (more births than deaths) in rural areas remained relatively stable over the two decades, this significant reduction in net migration dramatically slowed the rate of population increase. Indeed, the only two recent periods of significant rural population increase (the rebound of the 1990s and the turnaround of the 1970s) were fueled by migration.
For those counties not adjacent to metro areas, their much smaller net migration gains sharply reduced their population growth rate. Migration gains in more remote areas totaled only 46,000 ( 0.3 percent) and just 35 percent of these counties gained migrants. In contrast, during the 1990s, the migration gain was 544,000 in these counties. ${ }^{3}$ In adjacent rural counties, the migration gain was a far more sizable 3 percent $(980,000)$. Overall, 53 percent of the adjacent counties gained migrants between 2000 and 2010. Nonetheless, this recent migration gain was considerably smaller than it was during the 1990s, when adjacent counties gained 2.4 million migrants (7.4 percent). ${ }^{4}$

With little growth from net migration, natural increase became the major source of nonmetropolitan population growth between 2000 and 2010, accounting for just over half of the gain of 2.2 million rural residents. In fact, in remote rural counties, the natural increase of 418,000 (2.5 percent) represented 90 percent of the population gain. In adjacent nonmetropolitan counties, natural increase was 760,000 (2.4 percent). Here the contributions of natural increase and net migration were more balanced, with natural increase accounting for 44 percent of the population increase of 1.7 million.

Paradoxically, natural increase was responsible for most of rural population growth between 2000 and 2010, even though there was less natural increase during the decade than during the 1990s. In essence, the demographic impact of natural increase grew because rural net migration declined sharply after 2000. Because there were fewer births and more deaths between 2000 and 2010, there was a sharp rise in natural decrease (when more people die than are born) in rural counties. Overall, natural decrease is unusual in the American experience. Yet, in many rural counties, deaths have exceeded births for decades. ${ }^{5}$ Between 2000 and 2010, nearly 750 nonmetropolitan counties ( 36 percent) experienced overall natural decrease, up from approximately 29 percent in the 1990s. This represents the highest level of sustained natural decrease in U.S. history. ${ }^{6}$

The incidence and severity of natural decrease is influenced by proximity to metropolitan areas. Nearly 43 percent of remote nonmetropolitan counties-those not adjacent to a metropolitan area-had natural decrease between 2000 and 2010. In contrast, only 30 percent of the counties adjacent to metropolitan counties experienced natural decrease. The rising incidence of natural decrease coupled with dwindling migration gains is a cause for significant concern in some rural areas because it drains the demographic resilience from the local population, leaving limited potential for future population growth. ${ }^{7}$ 


\section{Demographic Change in County Types}

Rural demographic change is hardly uniform, as is evident when comparing shifts by a county's dominant economy. Farming and mining no longer monopolize the overall rural economy, but they have hardly disappeared (see Farming Counties on page 10). Farming still dominates the local economy of some 403 rural counties out of 2,151. Mining (which includes oil and gas extraction) is a major force in another 113 counties. However, these counties are largely at a demographic standstill in growth. Between 2000 and 2010, the population of farmingdependent counties grew by just 0.3 percent, and only 29 percent gained population (Figure 4). This minimal population gain was entirely due to a natural increase gain of 3.0 percent, which was large enough to offset a migration loss. In contrast, in the $1990 \mathrm{~s}$, farm counties grew by 5.0 percent with contributions from both natural increase and migration. Mining counties were also entirely dependent on natural increase for their modest population gain of 2.7 percent. In all, just 56 percent of the mining counties gained population between 2000 and 2010 .

Figure 4. DEMOgRAPHIC CHANGE BY NONMETROPOLITAN COUNTY TYPE, 1990 TO 2010

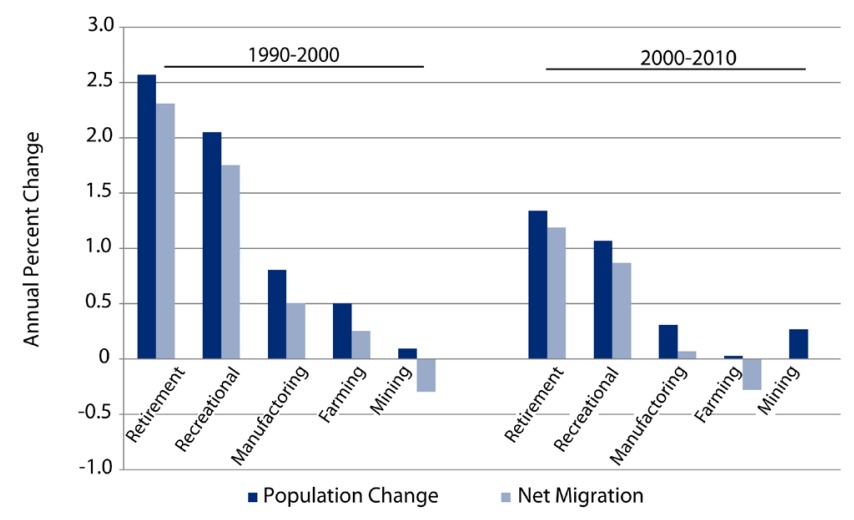

Source: US Census 1990-2010 and USDA Economic Research Service 2004

Counties dominated by manufacturing have traditionally been one of the bright spots of rural demographic change (see Manufacturing Counties on page 10). In fact, rural development strategies have traditionally focused on expanding the manufacturing base. ${ }^{8}$ There are 584 rural manufacturing-dominant counties, and their populations grew by 8.1 percent during the 1990s, mostly from migration. However, growth slowed dramatically in the new century.
The net population gain was only 3.1 percent between 2000 and 2010, though most manufacturing counties (57 percent) did continue to grow. A gain from natural increase of 430,000 accounted for 75 percent of this population gain in manufacturing counties. In contrast, migration contributed only modestly to the population growth, and less than half (47 percent) of the manufacturing counties gained from migration. The globalization of manufacturing coupled with the recent severe recession adversely impacted the rural manufacturing sector, as low skill, low-wage jobs have shifted offshore or disappeared as technology has replaced labor on the shop floor (see Straddling an Economic Transformation on page 10$){ }^{9}$

The demographic story was quite different in rural counties with natural amenities, recreational opportunities, or quality of life advantages (see Recreational Counties on page 10). Counties rich in amenities have consistently been the fastest growing in rural America. Major concentrations of these counties exist in the mountain and coastal regions of the West, in the upper Great Lakes, in coastal and scenic areas of New England and upstate New York, in the foothills of the Appalachians and Ozarks, as well as in coastal regions from Virginia to Florida. ${ }^{10}$

The 277 rural counties that are destinations for retirees exemplify this fast-growth trend, with population gains of 13.4 percent between 2000 and 2010. The 299 nonmetropoli$\tan$ recreational counties were close behind at 10.7 percent. Overall, 84 percent of the retirement destination counties and 69 percent of the recreational counties gained population during the decade.

There is considerable overlap in patterns between these two types of counties because the natural and built amenities that attract vacationers and second home owners also attract retirees. Nearly 90 percent of the population gain in retirement counties and 81 percent of the gain in recreational counties was fueled by migration. These migration streams include migrants moving for quality of life reasons, as well as other migrants attracted by economic opportunities generated by new growth. Yet even among these fast-growing rural counties, population gains slowed between 2000 and 2010. While still exceeding the national average, the gains were only half as great as those during the 1990s in the same groups of counties. 


\section{The Demographic Impact of Racial and Ethnic Minorities}

Any analysis of recent demographic trends in rural America must recognize the growing impact of minority populations. Between 2000 and 2010, the minority population, which included everyone other than non-Hispanic whites, accounted for 82.7 percent of the nonmetropolitan population gain, even though minorities represented just 21 percent of the rural population. The minority population grew by 1.8 million (21.3 percent) during the decade compared with a gain of just 382,000 (0.95 percent) among the much more numerous non-Hispanic white population. Thus, while nonmetropolitan America remains less diverse than urban America, minority growth now accounts for most rural population increase, just as it does in urban areas.

Patterns of racial diversity have been uneven across rural America (Figure 5). Many counties remain overwhelmingly non-Hispanic white, but racial diversity is substantial and increasing rapidly in other areas. Large concentrations of African Americans remain in rural areas of the Southeast, bolstered now by a recent influx of black migrants from other regions, although most continue to relocate in southern cities. Hispanics are spreading out beyond their historic roots in the Southwest into the Southeast and Midwest. ${ }^{11}$ About one-half of the nonmetropolitan Hispanic population now resides outside the rural Southwest. ${ }^{12}$ These resettlement patterns together with Hispanic natural increase have been instrumental in offsetting non-Hispanic white population declines,

\section{FIgURE 5. NONMETROPOLITAN MINORITY POPULATION DISTRIBUTION, 2010}

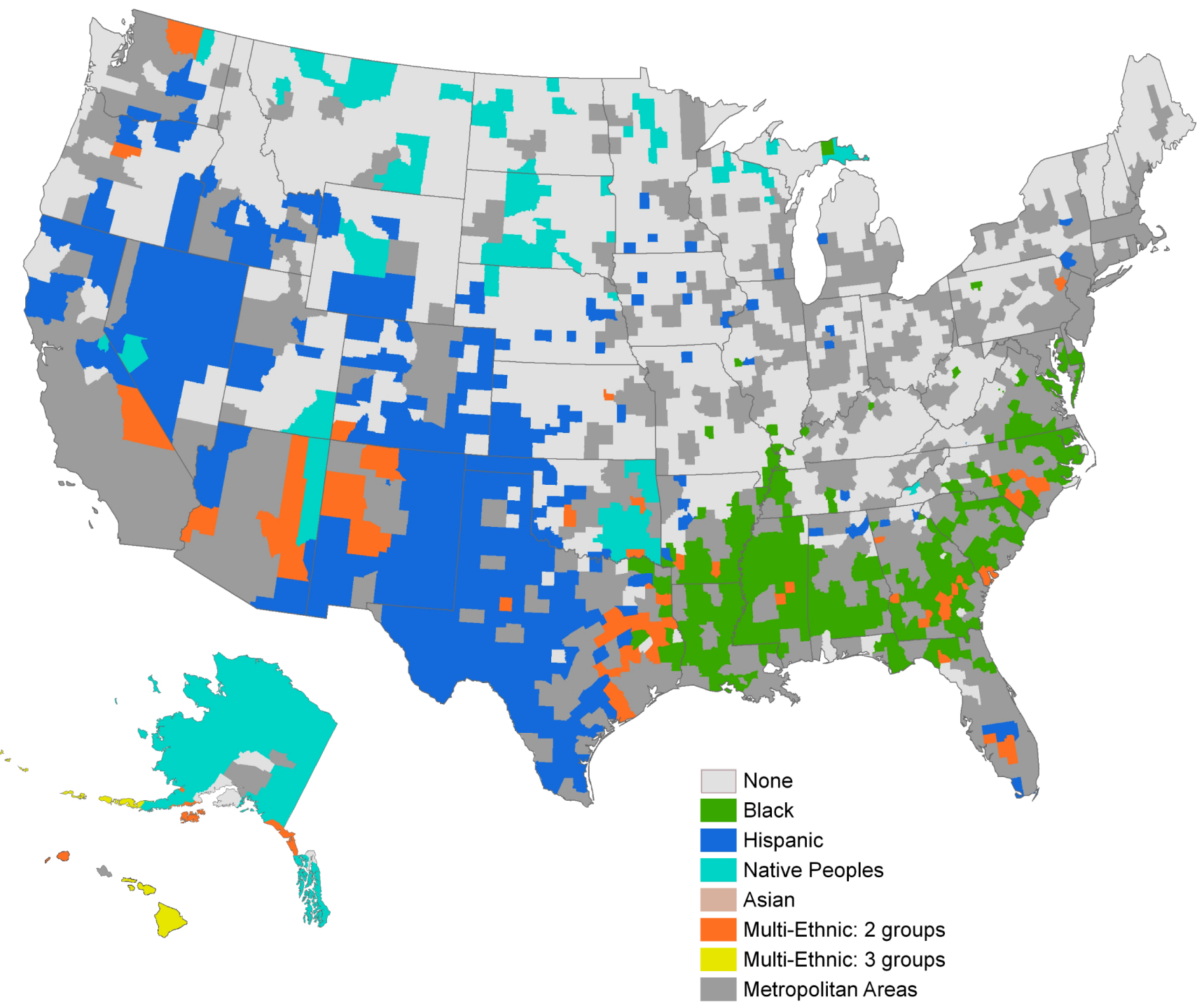


Figure 6. Percentage of NONMETRopolitan POPULATION AND POPULATION CHANGE BY RACE

AND HISPANIC ORIGIN, 2000 TO 2010

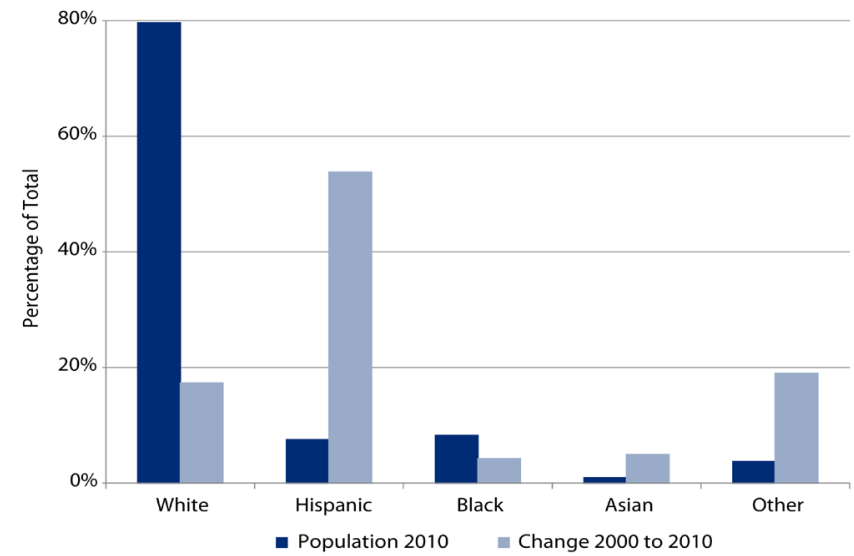

Source: US Census 2000 and 2010

especially in the Great Plains. Over 200 nonmetropolitan counties-double the number observed for the 1990s-would have experienced population decline between 2000 and 2005 without Hispanics migrants and natural increase. ${ }^{13}$

Figure 6 shows Hispanics' substantial impact on recent rural demographic change. During the 1990s, Hispanics accounted for 25 percent of the entire rural population gain, even though they represented just 3.5 percent of the rural population. This contribution to rural growth accelerated after 2000, when Hispanics accounted for 54 percent of the rural gain, while representing only 5.4 percent of the population in 2000. By 2010, the Hispanic population in rural America stood at 3.8 million, a gain of 45 percent from 2000. Hispanic migration is now having large secondary demographic effects on fertility and natural increase. ${ }^{14}$ Between 2000 and 2005, 58 percent of the nonmetropolitan Hispanic increase was due to the excess of births over deaths. ${ }^{15}$

Although small in overall numbers, native peoples also represent an important element of many rural communities in the Great Plains and in parts of the West. Surprisingly, there are few multi-ethnic counties in rural America. In the Southwest, native peoples and Hispanics reside together in a few counties, and there are scattered pockets of blacks and Hispanics co-residing in the Southeast and East Texas. But in general, although diversity is growing in rural America, it is doing so on a modest scale with one or at most two minority groups residing in the same rural county.

Children are in the vanguard of this growing diversity in nonmetropolitan areas. Nationwide, minority children represented 46 percent of the U.S. population under age 18 in 2010. In contrast, only 33 percent of the adult population is minority. Patterns are similar in rural America,
Figure 7. NONMETROPOLITAN POPULATION BY RACE AND HISPANIC ORIGIN, 2010
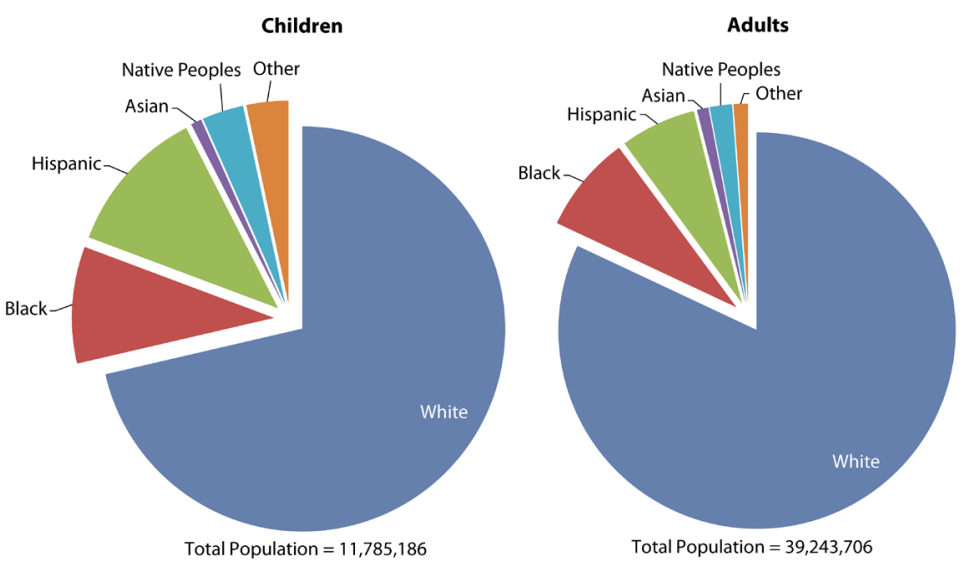

Source: U.S. Census 2010

where nearly 28 percent of the child population is minority compared with 18 percent of the adult population (Figure 7). At more than 12 percent in 2010, Hispanics represent the largest share of this minority youth population in rural areas. ${ }^{16}$

The conventional wisdom is that this growing racial and ethnic diversity is largely a big-city phenomenon. However, the absolute growth of minority children-especially Hispanic children-is also evident in rural areas, even as the overall child population there declined by nearly 515,000

Figure 8. Absolute ANd PERCENT CHANGe in CHILD POPULATION BY RACE/HISPANIC ORIGIN, 2000 TO 2010

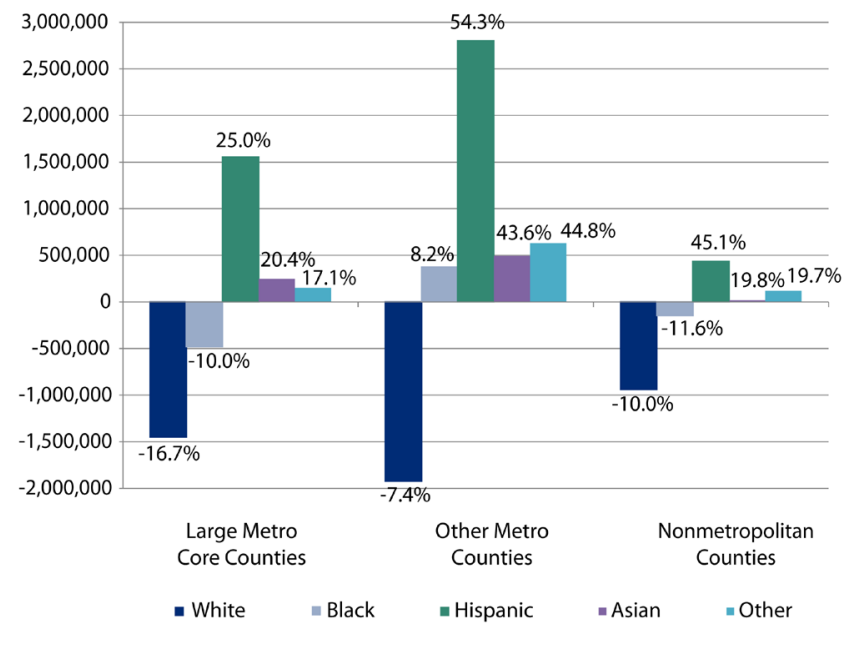

Source: U.S. Census 2000 and 2010 
(-4.2 percent) between 2000 and 2010 (data not shown). Figure 8 reflects both the absolute and percentage change in the child population between 2000 and 2010. It shows that the number of non-Hispanic white children declined by 940,000 (-10.0 percent) in rural areas, while the number of black children declined by 11.6 percent. The overall loss of children in rural areas was cushioned by a Hispanic child population gain of 434,000 children (45.1 percent). The significant loss of white children coupled with a growing Hispanic child population accelerated the diversification of the rural child population.
Today, 591 counties have more minority than white children (so-called "majority-minority" counties) and another 300 are "near" majority-minority, with between 40 and 50 percent minority youth populations (Figure 9). Of these, 356 majority-minority youth counties are nonmetropolitan as are 178 of the near majority-minority counties. These rural majority-minority counties are concentrated in the Mississippi Delta, the Rio Grande region, the Southeast, and in the Northern Great Plains. Young people clearly are a harbinger of future racial-ethnic change and diversity in rural America, as deaths among the older largely white population are replaced disproportionately by minority births.

Figure 9. NONMETROPOLITAN MINORITY CHILD POPULATION CONCENTRATION, 2010

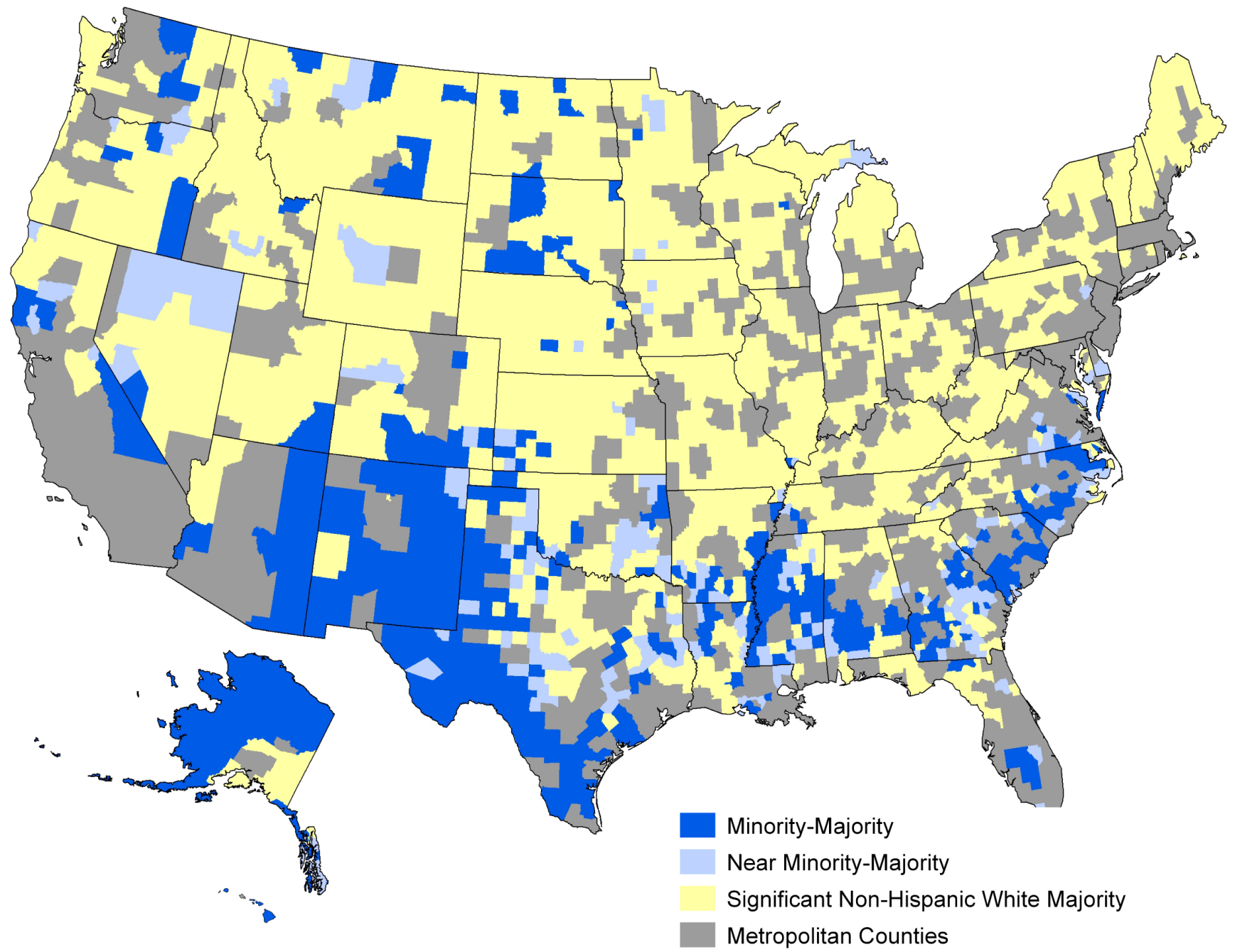




\section{Discussion and Policy Implications}

The story of demographic change in rural America in the first decade of the twenty-first century is a story of slowing growth as a result of slowing migration, coupled with growing diversity. Rural population gains were considerably smaller than they had been during the rural rebound of the 1990s. Nonmetropolitan areas grew by just 2.2 million people between 2000 and 2010, barely half the growth of the 1990s. The slower population growth in rural America occurred because migration contributed far less to the rural population increase than it had during the 1990s. Paradoxically, natural increase (more births than deaths) re-emerged as the primary demographic force fueling rural growth not because of a surge in rural births, but because migration to rural America has sharply diminished.

The first decade of the twenty-first century also highlights new patterns of racial and ethnic diversity in rural America. Hispanics in particular represent a new source of demographic vigor in parts of rural America, especially in the Midwest and Southeast. The minority population represents just 21 percent of the rural population, but minorities produced nearly 83 percent of the rural population increase between 2000 and 2010. Hispanics accounted for more than half of the rural population gain in the last decade, though they represent just 7.5 percent of the rural population in 2010.

Two powerful demographic forces place young people in the vanguard of America's new diversity. The first is the increase in the number of minority children. A second and even more dramatic force in rural America is the absolute decline in the population of non-Hispanic white youth. The proportion of minority children is now growing rapidly in many parts of rural America. Yet, there are still broad rural regions where interaction between young people from different race-ethnic backgrounds is limited.

These demographic changes have important policy implications. First, as rural America becomes more racially and ethnically diverse, rural institutions that serve young people, such as education and health care, will be the first to feel the impact and new challenges of this growing diversity. Such institutions are among the most expensive for local governments. Adjusting to growing diversity is a financial challenge for communities during the best of times, much less when they face the worst recession in a generation. Nor are financial problems the only challenges rural communities face in dealing with diversity. Hispanics are transforming the social fabric of many small towns, while raising important policy questions (such as schooling, political participation, and racial tensions) about their successful incorporation into American society. ${ }^{17}$

The second policy implication stems from a familiar problem: high and persistent child poverty. Recent research by the Carsey Institute documents the stubborn persistence of child poverty in large areas of rural America. ${ }^{18}$ By definition, persistent poverty is high levels of child poverty for at least thirty years. In all, 571 of the 706 U.S. counties with persistent child poverty ( 81 percent) are in rural America. More than 26 percent of the rural child population resides in these counties with persistent poverty. This compares with just 12 percent of urban children. The recession has only worsened this situation with the proportion of children in poverty rising in these already disadvantaged counties. Nor is persistent child poverty limited to a few isolated pockets or to minority children. It is widespread in largely white areas of Appalachia and the Ozarks, just as it is in black areas of the Mississippi Delta, Native American areas of the Great Plains, and in Hispanic enclaves in the Rio Grande Valley. The demographic changes that rural America has experienced over the last decade have done nothing to alleviate persistent poverty. The social and economic isolation fostered by distance and limited transportation that many of the rural poor face are among the reasons why welfare reform, expansion of government health insurance, and education reforms affect children differently in rural areas than in cities and suburbs. In the face of government spending cutbacks and two decades of shifting policy-making responsibility from the federal to state and local governments, it is imperative that policymakers be cognizant of the continuing vulnerability of the rural child population.

A final policy implication stems from the varied patterns of population change. Although population growth is slowing overall in rural America, some communities are thriving. For fast-growing rural counties, including those just beyond the urban edge as well as in amenity-rich areas, programs and expertise are needed to address the complex issues of managing growth and development. These needs are particularly acute in communities with recreational and natural amenities. In such areas, rapid population increase puts additional pressure on the environmentally sensitive riparian, forest, historical, and scenic areas that originally attracted migrants, but now may be overwhelmed by them. Managing rapid growth represents a serious challenge that many rural governments are simply not prepared to meet, especially during a major recession that is stretching their limited resources even thinner.

In contrast, in remote rural agricultural areas, the population slowdown has been profound. In hundreds of these counties, more people are now dying than being born and young adults continue to leave, as they have for decades. Here rural policy must ameliorate the adverse impacts of a diminishing population on the provision of critical services and support programs as well as provide access to the resources (internet, capital, and expertise) needed to expand the local infrastructure and enhance future development opportunities.

In all cases, policymakers must understand the varied patterns of demographic change in rural communities and design policies that are comprehensive enough to address the multi-faceted challenges these communities face. 
The 2003 New Homestead Act, which was sponsored by a bipartisan group of farm-state senators, exemplifies the kind of comprehensive legislation needed to address the complex needs of rural areas. Designed to stem population loss, the bill targeted nonmetropolitan counties that lost more than 10 percent of their population from outmigration during the past twenty years. Some 698 counties qualified for the program, including the four farm counties we highlight-Jewell, Osborne, Republic, and Smith. Modeled on the original Homestead Act of 1862, which offered government land to anyone willing to settle on and work it for five years, the New Homestead Act offered incentives to individuals and businesses to encourage them to stay in or move to counties with histories of migration loss. For individuals, incentives included repayment of college loans, tax credits for home purchases, protection of home values, and tax-free accounts to build savings and increase access to credit. For businesses, incentives included investment tax credits, micro-enterprise tax credits, and a venture capital fund.

Unfortunately, the legislation never made it out of committee. Nonetheless, the New Homestead Act exemplifies the type of comprehensive, multifaceted bill needed to address many of the challenges that caused population loss.

The fates of rural and urban America are increasingly linked in the new century. ${ }^{19}$ However, policies to address the needs of America's 100 largest metropolitan areas may not yield similar successes in rural America, where distances are greater, isolation is common, and agglomeration advantages are fewer and farther between. Only comprehensive policies, such as the New Homestead Act, that are fully cognizant of the special needs of rural communities and informed by input from local rural leaders can address the emerging demographic, economic, and spatial challenges that many rural communities face. Improving the opportunities, accessibility, and viability of rural areas is critical both to the 51 million rural residents and to the larger nation that depend on the contributions rural America makes to the material, environmental, and social well-being of the nation.

\section{Data and Methods}

Counties are the unit of analysis. They have historically stable boundaries and are a basic unit for reporting fertility, mortality, and census data by the federal government. Counties are also appropriate units of analysis because metropolitan areas are built up from them (county-equivalents are used for New England). We designate counties as metropolitan or nonmetropolitan using criteria developed by the U.S. Office of Management and Budget. We use a constant 2004 metropolitan-nonmetropolitan classification. Such a fixed definition of nonmetropolitan and metropolitan removes the effect of reclassification from the calculation of longitudinal population change.

Metropolitan areas include counties containing an urban core of 50,000 or more population (or central city), along with adjacent counties that are highly integrated with the core county as measured by commuting patterns. There are 1,090 metropolitan counties. The remaining 2,051 counties are classified as nonmetropolitan. For ease of exposition, we use the terms "metropolitan" and "urban" (and "nonmetropolitan" and "rural") interchangeably. In some analyses, we have further identified large metropolitan core counties in metropolitan areas of 1 million or more, and consider them separately from all other metropolitan counties.

We also classify counties using a typology developed by the Economic Research Service of the U.S. Department of Agriculture that groups nonmetropolitan counties along economic and policy dimensions. ${ }^{20}$ County population data come from the decennial census for 1990, 2000, and 2010. They are supplemented with data from the Federal-State Cooperative Population Estimates program (FSCPE), which provides information on births and deaths in each county for April 2000 to July 2009. ${ }^{21}$ We estimated births and deaths from July 2009 to the census in April 2010 at .75 of the amount from July 2008 to July 2009 . We derived the estimates of net migration by the residual method, whereby net migration is what is left when natural increase (births minus deaths) is subtracted from total population change.

Data for the racial and Hispanic origin of the population are from the 2000 and 2010 census. Five ethnoracial groups are identified: (1) Hispanics of any race, (2) nonHispanic whites, (3) non-Hispanic blacks, (4) non-Hispanic Asians, and (5) all other non-Hispanics, including those who reported two or more races. In some analyses, Native Americans are reported separately. To examine the spatial distribution of different racial and ethnic child populations, we estimated the number and percentage of majority-minority counties - those having at least half their child population from minority groups in 2010-and near majority-minority counties - those with between 40 percent and 50 percent of their children from minority populations.

We also classified counties as having minority concentrations if more than 10 percent of the population was from a specific minority group. Black, Hispanic, Asian, and Native American were the four minority groups that reached the 10 percent threshold in at least one county. We classified counties that had two or more minority groups reaching the 10 percent threshold as multi-ethnic. 


\section{County Snapshots}

\section{Farming Counties}

Rural America was originally settled by people whose livelihood depended on their ability to wrestle food, fiber, and minerals from the land. The USDA defines 403 farmdependent counties that represent this traditional rural sector. Among them are Jewell, Osborne, Republic, and Smith counties in Kansas. Situated along the Nebraska-Kansas border and straddling the boundary between the corn and wheat belts, these counties have a very large proportion of their labor force engaged in agriculture and are far removed from the urban scene.

In 1900 , nearly 66,000 people lived and farmed in these four counties. The population has declined ever since. By 1990 , only 20,700 people remained. The population dropped another 24 percent in the next twenty years, leaving just 15,800 people in 2010 . Young adults have historically left these farm counties in large numbers. In contrast, the older population stays. As a result, all four counties experienced overall natural decrease in each of the last four decades.

These farming-dependent counties do enjoy significant advantages. Unemployment and poverty levels are low. Incomes and housing prices are moderate, producing an affordable standard of living. Residents find these farm counties appealing because they believe their neighbors will help out when needed, people get along, and residents work together well in their communities. ${ }^{22}$ The continuing loss of people and jobs despite strong local social and community capital reflects the dilemma facing many rural farm counties. Addressing this requires comprehensive policy initiatives that capitalize on local social and community capital to encourage people, business, and institutions to stay in the region as well as attract new residents.

\section{Recreational Counties}

Michigan's Grand Traverse County exemplifies the fast growing recreational and retirement destinations discussed in this report. Situated on a beautiful Lake Michigan bay in Michigan's Lower Peninsula, the county is well known for its crystal clear lakes, ski slopes, golf courses, restaurants, and lodging. It has a well-earned reputation as a year-round recreational center, but its economy is actually quite diverse.

Grand Traverse amenities attract retirees and the creative classes seeking an alternative to the hectic pace of urban life. The result has been rapid population increase, from 39,175 in 1970 to 64,273 in 1990, a 64 percent gain in just twenty years. Growth continued in the 1990s with a gain of 20.8 percent. Most of the growth came from migration, with a substantial flow from the metropolitan areas of southern Michigan and Chicago. Growth slowed to just 12 percent after 2000, as it has in many recreational areas, as a result of slowing migration, especially as the recession has deepened. Even the fast growing amenity regions are not immune to economic forces.

Grand Traverse's history of growth has expanded employment opportunities, making it easier for residents to stay and for workers from surrounding areas to move in. But this growth has had negative consequences as well, with some concerned about the impact that so much growth will have on the environment and quality of life in the community.

\section{Manufacturing Counties}

Surry County in North Carolina is nestled against the Virginia border in the scenic foothills of the Smokey Mountains. The county has a long history as a center of rural manufacturing mostly in furniture making and textiles, but both of those sectors are fading and jobs are disappearing. ${ }^{23}$ Poultry processing is growing in the county, as it is in much of the rural Southeast, but jobs are still scarce. Tourism is also on the rise because of the county's beauty and its proximity to the growing urban areas to the South.

The county has had its demographic ups and downs. Surry's population grew by 15.6 percent during the rural turnaround of the 1970s and by 15.4 percent during the rebound of the 1990s. Migration fueled almost all of this growth. Growth has diminished sharply since 2000, with the county growing by just 3.5 percent because net migration fell to less than 20 percent of its 1990s level. Surry County's recent demographic change illustrates the growing diversity of rural America as well. Hispanics accounted for virtually all of the recent population gain, growing by more than 50 percent between 2000 and 2010 and now representing nearly 10 percent of the population. Prior research by the Carsey Institute highlights the challenges that Surry and many other rural counties face as their populations become more diverse. ${ }^{24}$

\section{Straddling an Economic Transformation}

In New Hampshire's northernmost county, Coös County, a declining manufacturing and resource extraction base coupled with growing recreational activity, has produced an unusual demographic profile. For more than 100 years, wood and paper products were a mainstay of the economy, with large mills employing generations of residents processing the timber of the vast northern forests. Today, only one mill remains and its future is precarious. Yet, Coös County is also situated in a scenic region with ski areas and grand old resorts that have welcomed generations of vacationers and now amenity migrants. 
Coös County currently has 33,100 residents, roughly 1,200 fewer residents than it had in 1970, and it has lost population in each of the last three decades. There were 3,000 births in Coös County between 2000 and 2010, but more than 4,100 deaths. This produced a natural population loss of 3.3 percent. Coös also experienced natural decrease in the 1990s. Yet between 2000 and 2010, Coös County gained migrants because of its recreational appeal. This migration gain offset most of the natural decrease resulting in a population decline of just 56 people (.2 percent), a considerable improvement over the loss of nearly 1,700 during the 1990s.

The differing influence of manufacturing and recreation is evident in local migration patterns. Coös County is still losing many of its 20- to 39-year-olds, which is common to many extractive-based counties (forestry, farming, and mining). Working-aged adults must often leave to seek opportunities elsewhere. At the same time, the modest influx of those aged 50 to 59 is common in recreation-based counties. ${ }^{25}$

Coös County is seeking to capitalize on its growing recreational appeal through a county-wide effort to create a common brand. The effort must overcome the fierce independence of local communities in the "live free or die" state, however. ${ }^{26}$ Such rebranding and regional cooperation is an important strategy for rural communities to consider as they attempt to adapt to the economic and demographic transformation facing rural America in the new century.
E N D N O T E S

1. We use the terms metropolitan and urban (and nonmetropolitan and rural) interchangeably.

2. Kenneth M. Johnson, "Demographic Trends in Rural and Small Town America," Reports on Rural America, vol. 1, no. 1 (Durham, NH: Carsey Institute, 2006), pp.1-35.

3. Kenneth M. Johnson and John B. Cromartie, “The Rural Rebound and Its Aftermath: Changing Demographic Dynamics and Regional Contrasts." In Population Change and Rural Society, edited by W. Kandel and D. L. Brown (Dordrecht, Netherlands: Springer, 2006).

4. Immigration contributed more to rural migration gains between 2000 and 2010 than it did during the 1990s. No definitive immigration data are currently available for the period, but estimates from 2000 to 2009 suggest a substantial inflow of immigrants to both adjacent and nonadjacent counties. However, even with immigration on the rise, overall migration gains were significantly smaller in rural areas during the first decade of the twenty-first century.

5. Kenneth M. Johnson and Calvin. L. Beale, "Natural Population Decrease in the United States," Rural Development Perspectives, vol. 8 (1992): 8-15.

6. Kenneth M. Johnson, "The Continuing Incidence of Natural Decrease in American Counties," Rural Sociology, vol. 76, no. 1 (2011): 74-100.

\section{Ibid.}

8. Manufacturing is an important component of the rural economy employing a larger proportion of the rural labor force than it does in urban areas. See Johnson, "Demographic Trends in Rural and Small Town America."

9. Johnson, "Demographic Trends in Rural and Small Town America"; and Johnson and Cromartie, "The Rural Rebound and Its Aftermath."

10. Kenneth M. Johnson and Calvin L. Beale, "Nonmetro Recreation Counties: Their Identification and Rapid Growth," Rural America 17 (2002): 12-19; David. A. McGranahan, "Natural Amenities Drive Population Change," Agricultural Economics Report no. 718 (Washington, DC: Economic Research Service, U. S. Department of Agriculture, 1999); Economic Research Service, "Measuring Rurality: 2004 County Typology Codes Methods, Data Sources, and Documentation" (Washington, DC: U.S. Department of Agriculture), available online at http://www.ers.usda.gov/Briefing/Rurality/Typology/ Methods (retrieved July 15, 2011).

11. William Kandel and John Cromartie, New Patterns of Hispanic Settlement in Rural America, Rural Development Research Report no. 99 (Washington, DC: Economic Research Service, USDA, 2004); Kenneth M. Johnson and Daniel T. Lichter, "Natural Increase: A New Source of Population 
in Emerging Hispanic Destinations in the United States," Population and Development Review, vol. 34 (2008): 327-346.

12. Johnson and Lichter, "Natural Increase."

13. Kandel and Cromartie, New Patterns of Hispanic Settlement in Rural America; Johnson Lichter, "Natural Increase."

14. Johnson and Lichter, "Natural Increase"; Kenneth M. Johnson and Daniel T. Lichter, "The Growing Diversity of America's Children and Youth: Spatial and Temporal Dimensions," Population and Development Review, vol. 31, no. 1 (2010): 151-176.

15. Johnson and Lichter, "Natural Increase."

16. Johnson and Lichter, "The Growing Diversity of America's Children and Youth.”

17. Douglas S. Massey, New Faces in New Places: The Changing Geography of American Immigration (New York: Russell Sage Foundation, 2008).

18. MaryBeth Mattingly, Kenneth M. Johnson, and Andrew P. Schaefer, "More Poor Kids in More Poor Places," Carsey Institute Policy Brief (Durham, NH: Carsey Institute, University of New Hampshire, 2011).

19. Daniel T. Lichter and David. L. Brown, "Rural America in an Urban Society: Changing Spatial and Social Boundaries," Annual Review of Sociology, vol. 37 (2011): 565-592.

20. Economic Research Service, "Measuring Rurality."

21. U.S. Census Bureau, "Annual County Resident Population Estimates by Age, Sex, Race, and Hispanic Origin: April 1, 2000 to July 1, 2009" (Washington, DC: U.S. Census Bureau, 2010), available at http://www.census.gov/popest/ counties/counties.html (retrieved August 30, 2011).

22. Larry C. Hamilton et al., Place Matters: Challenges and Opportunities in Four Rural America. A Carsey Institute Report on Rural America (Durham, NH: Carsey Institute, University of New Hampshire, 2008).

23. Johnson, "Demographic Trends in Rural and Small Town America."

24. Ibid.

25. Kenneth M. Johnson et al., "Temporal and Spatial Variation in Age-Specific Net Migration in the United States," Demography, vol. 42, no. 4 (2005): 791-812.

26. Michele Dillon, "Stretching Ties: Social Capital in the Rebranding of Coös County, New Hampshire," New England Issue Brief (Durham, NH: Carsey Institute, University of New Hampshire).

\section{A B OUT THE AUTHORS}

Kenneth M. Johnson is senior demographer at the Carsey Institute and professor of sociology at the University of New Hampshire (ken.johnson@unh.edu).

\section{A C K N O W L E D G M E N T S}

This research was supported by a grant from AGree, a project of the Meridian Institute. Research assistance was provided by Luke Rogers and Barb Cook of the Carsey Institute. Thanks to Leif Jensen at Pennsylvania State University; Daniel Lichter at Cornell University; Barbara Ray at Hired Pen; and Bruce Mallory, Curt Grimm, Amy Sterndale, and Laurel Lloyd at the Carsey Institute for their helpful comments and suggestions.

\section{ANIVERSITY
of NEW HAMPSHIRE}

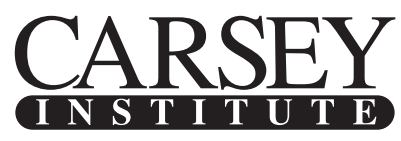

Building knowledge for families and communities

The Carsey Institute conducts policy research on vulnerable children, youth, and families and on sustainable community development. We give policy makers and practitioners timely, independent resources to effect change in their communities.

This research was supported by a grant from AGree, a project of the Meridian Institute, as well as the Annie E. Casey Foundation, the W. K. Kellogg Foundation, and an anonymous donor.

Huddleston Hall

73 Main Street

Durham, NH 03824

(603) $862-2821$

www.carseyinstitute.unh.edu 